\title{
A fully validated microbiological assay for daptomycin injection and comparison to HPLC method
}

\author{
Ana Paula Christ ${ }^{1}$, Mariana Souto Machado', Karla Giacomelli Ribas ${ }^{1}$, Alexandre Vargas \\ Schwarzbold ${ }^{2}$, Cristiane de Bona da Silva ${ }^{1}$, Andréa Inês Horn Adams ${ }^{1, *}$
}

\author{
${ }^{1}$ Department of Industrial Pharmacy, Federal University of Santa Maria, Santa Maria, RS, Brazil, ${ }^{2}$ Universitary Hospital of \\ Santa Maria, Santa Maria, RS, Brazil
}

\begin{abstract}
Daptomycin (DPT) was the first lipopeptide antibiotic available for commercialization. It is active against gram-positive bacteria, including resistant strains. This work aimed to develop and validate a turbidimetric microbiologic assay to determine daptomycin in an injectable form. A $3 \times 3$ design was employed, at concentrations of 1, 2 and $4.0 \mu \mathrm{g} / \mathrm{mL}$. The microorganism test used was Staphylococcus aureus ATCC 6538p, and Antibiotic Medium 3 was used as the culture medium. Method validation demonstrated that the bioassay was linear $(\mathrm{r}=0.9995)$, precise $(\mathrm{RSD}=2.58 \%$ ), accurate (recovery $100.48 \pm$ $2.11 \%$ ), and robust. Degradation kinetics was also performed in an alkaline medium, indicating that daptomycin degradation follows first order kinetics under these conditions. The analyses of degraded solutions showed that daptomycin degradation products do not possess bactericidal activity. The bioassay was compared to HPLC method that was previously developed and no significant difference was found between them $(\mathrm{p}>0.05)$. The method proved to be appropriate for daptomycin injection quality control.
\end{abstract}

Uniterms: Daptomycin/determination. Daptomycin injection/quality control. Turbidimetric microbiological assay/quantitative analysis.

\begin{abstract}
A daptomicina (DPT) é o primeiro lipopeptídeo cíclico disponível para comercialização. Possui atividade frente a bactérias gram-positivas, incluindo cepas resistentes. O objetivo deste trabalho foi desenvolver e validar um ensaio microbiológico turbidimétrico para quantificar a daptomicina na forma injetável. Empregou-se delineamento 3x3, nas concentrações de 1,0;2,0 e 4,0 $\mu \mathrm{g} / \mathrm{mL}$. Como micro-organismo teste foi usado Staphylococcus aureus ATCC 6538p, e Meio para Antibióticos $\mathrm{n}^{\circ} 3$ foi empregado como meio de cultura. A validação do método demonstrou que o ensaio foi linear $(\mathrm{r}=0,9995)$, preciso $(\mathrm{RSD}=2,55 \%)$, exato (recuperação de $100,48 \pm 2,11 \%$ ) e robusto. A cinética de degradação em meio alcalino foi avaliada, indicando que a daptomicina segue cinética de primeira ordem nessa condição. A análise das soluções degradadas mostrou que os produtos de degradação da daptomicina não possuem atividade antimicrobiana. O bioensaio foi comparado com o método por CLAE previamente desenvolvido e não houve diferença significativa entre ambos $(\mathrm{p}<0,05)$. O método mostrou-se apropriado para o controle de qualidade da daptomicina injetável.
\end{abstract}

Unitermos: Daptomicina/determinação. Daptomicina injetável/controle de qualidade. Ensaio microbiológico turbidimétrico/análise quantitativa.

\section{INTRODUCTION}

When the first antibiotics, such as penicillin, began to be used in clinical medicine, around 1940, they were considered miracle drugs because they were able

\footnotetext{
*Correspondence: A. I. H. Adams. Departamento de Farmácia Industrial. Universidade Federal de Santa Maria. Av. Roraima, 1000 - Prédio 26/sala 1106, 97.105-900 - Santa Maria - RS, Brasil. E-mail: andrea.ih.adams@gmail.com
}

to treat serious infectious diseases, such as pneumonia and tuberculosis (Eom, Kim, Kim, 2013; Fernandes, 2006). However, the widespread use of antimicrobials created constant selective pressure that resulted in the survival and spread of resistant bacteria. Microorganism resistance to antimicrobial agents has been reported for several pathogens, such as Staphylococcus aureus, Klebsiella pneumoneae, Streptococcus pneumoneae, Mycobacterium tuberculosis and Enterobacter species, 
among others (Boucher et al., 2013; Spellberg et al., 2008).

New antibiotics have been approved over the last decade, such as: linezolid (US in 2000/EU in 2001), tigecycline (US in 2005/EU in 2006), DPT (US in 2003/ EU in 2006) and telavancin (US in 2009) (Boucher et al., 2013; Sakoulas, 2009).

The focus of this study is DPT (Figure 1), which is a cyclic lipopeptide with activity limited to gram-positive bacteria, such as Staphylococcus aureus, Enterococcus faecalis, and Streptococcus pneumoneae, including multidrug-resistant and susceptible strains (Koeth, Thorne, 2010; Lu et al., 2011; Steenbergen et al., 2005). The molecule is obtained from a strain of Streptomyces roseosporus and was originally known as LY 146032 (Debono et al., 1987; Eliopoulos et al., 1986). The action mechanism is physiologic calcium dependent and possibly involves the disruption of amino acid transport by the cell membrane and changes in the cytoplasmic membrane potential (Debono et al., 1987; Koeth, Thorne, 2010; Lu et al., 2011).

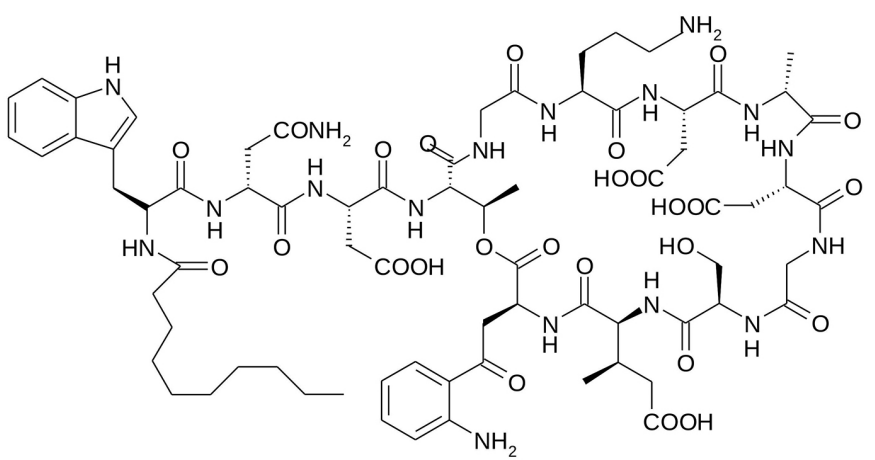

FIGURE 1 - Chemical structure of daptomycin.

Some LC methods have been reported in the literature in order to determine DPT in some biological fluids, such as serum (Deryke et al., 2006; Rybak et al., 1992; Tobin et al., 2008), blood (Gikas et al., 2009; Olszowy et al., 2010), and plasma (Baietto et al., 2010; Dvorchik et al., 2003; Martens-Lobenhofer et al., 2008; Verdier et al., 2011). Recently, an HPLC method focusing on the assay of daptomycin injection was reported, which is the only pharmaceutical form available (Christ et al., 2014). However, no methods to determine daptomycin in pharmaceutical form have been reported in the pharmacopoeias.

Because of increasing pathogen resistance and the difficulty in developing new antimicrobial drugs, it is relevant to ensure the quality of those available on the market. Two methods are commonly used to assay antibiotics in pharmaceuticals: agar diffusion and broth turbidity (turbidimetric assay). Both enable estimating antibiotic potency through a direct comparison of a test antibiotic with a reference substance. Using these assays, it is possible to perceive reduction in antimicrobial activity caused by subtle changes that are not demonstrable by chemical methods. Therefore, microbial or biological assays generally remain the standard for solving any doubt concerning a possible loss of activity (USP, 2007).

The aim of this study was to develop and validate a simple, specific, accurate, reproducible, and stabilityindicative turbidimetric microbiological assay to quantify injectable daptomycin. Moreover, a high performance liquid chromatographic (HPLC) method, developed and validated in our laboratory was chosen as a comparison method to determine daptomycin in degraded samples.

\section{EXPERIMENTAL}

\section{Chemical and reagents}

The DPT reference substance was supplied by Hisun Pharmaceutical Hangzhou, Co., Ltd. (Xukow Town, China) and was used as purchased. Cubicin ${ }^{\circledR}$ (Novartis, São Paulo, Brazil) containing $500 \mathrm{mg}$ of DPT in powder form for injection or infusion (excipient: sodium hydroxide) was kindly provided by Hospital Universitário de Santa Maria (HUSM) within their shelf life. Antibiotic Medium 1 and Antibiotic Medium 2 were obtained from Himedia (Brazil) and Antibiotic Medium 3 was obtained from Difco (Brazil). All the chemicals were of pharmaceutical or special analytic grade. For all the analyses, ultrapure water was purified using a Millipore MilliQ ${ }^{\circledR}$ A 10 water system (Billerica, MA, USA).

\section{Preparation of reference substance and sample solutions}

Both of the stock solutions (reference substance and sample) were prepared by dissolving the equivalent of $10 \mathrm{mg}$ of DPT and diluting with ultrapure water in order to obtain $100 \mu \mathrm{g} \mathrm{mL}^{-1}$ solutions. To conduct the microbiological assay, the stock solutions of reference substance and sample were prepared on the day of the assay and diluted with the same solvent to concentrations of 1,2 , and $4 \mu \mathrm{g} \mathrm{mL}^{-1}$.

\section{Preparation of a calcium stock solution}

A stock solution of calcium was prepared diluting $3.67 \mathrm{~g}$ of calcium chloride dihydrate in a volumetric flask of $100 \mathrm{~mL}$ with ultrapure water, obtaining a concentration 
of $36.7 \mathrm{mg} \mathrm{mL}^{-1}$ (equivalent to $10 \mathrm{mg} \mathrm{mL}^{-1}$ of calcium). This solution was sterilized, stored at $2-8^{\circ} \mathrm{C}$, and added to the culture medium after the sterilization process.

\section{Microorganism and inoculum standardization}

The microorganism that was used in this assay was Staphylococcus aureus ATCC 6538p. The microorganism was stored at $2-8{ }^{\circ} \mathrm{C}$ in Antibiotic Medium No. 1 agar. Twenty-four hours before the assay it was inoculated into another test tube with the same agar and incubated at $35 \pm 2{ }^{\circ} \mathrm{C}$. The bacteria was suspended and diluted in saline in order to obtain a suitable suspension with $25 \% \pm$ 2 of transmittance in $580 \mathrm{~nm}$, using a spectrophotometer (Shimadzu UV-1800). Saline was used as blank. This microorganism suspension (named inoculum) was stored at $2-8{ }^{\circ} \mathrm{C}$ for 7 days and was added to the fluid medium, as described in the next section.

\section{Turbidimetric method}

A $3 \times 3$ design was chosen for the development of the microbiological method. In this model, three standard and sample solutions in the same presumed concentration are compared in order to determine the antibiotic (FB $5,2010)$. At first, $1 \mathrm{~mL}$ of inoculum was added to 100 $\mathrm{mL}$ of sterilized Antiobiotic Medium 3. Then, $9 \mathrm{~mL}$ of inoculated medium and $1 \mathrm{~mL}$ of a sample or standard solution (at the concentration of 1,2 and $4 \mu \mathrm{g} \mathrm{mL}^{-1}$ ) were added to the test tube. After that, they were incubated at $37{ }^{\circ} \mathrm{C}$ for 5 hours in a water bath with circulation. Concomitantly, negative test tubes $(9 \mathrm{~mL}$ of Antibiotic Medium 3 and $1 \mathrm{~mL}$ of water) and positive test tubes ( $9 \mathrm{~mL}$ of inoculated Antibiotic Medium 3 and $1 \mathrm{~mL}$ of water) were incubated. All the test tubes were prepared in triplicate. The test tubes were randomly distributed in the water bath and the same time interval for loading and unloading each one was observed.

After incubation, the multiplication of microorganisms was stopped by the addition of $0.5 \mathrm{~mL}$ of $12 \%$ formaldehyde solution in each one of test tubes, including positive and negative controls. The absorbance of the samples, reference substance, and control test tubes was determined at $530 \mathrm{~nm}$, using the negative control as blank. The HEWITT equation was used to calculate de potency of DPT samples (Hewitt, 2003).

\section{Method validation}

The method was validated according to the International Conference on Harmonization (ICH, 2005) by determining the following parameters: specificity, linearity, precision, accuracy, and robustness.

\section{Specificity}

The capacity of the method to determine DPT in the presence of degradation products was evaluated by comparing the results obtained from the same sample degraded and analyzed by the HPLC method (previously validated by our research group) and microbiologic assay. To promote the drug degradation, $5 \mathrm{~mL}$ of DPT $100 \mu \mathrm{g} \mathrm{mL}^{-1}$ were mixed with $5 \mathrm{~mL}$ of sodium hydroxide $0.01 \mathrm{~mol} / \mathrm{L}$; after 30 minutes, the solution was neutralized with hydrochloric acid $0.1 \mathrm{~mol} / \mathrm{L}$. After neutralization, 1 $\mathrm{mL}$ of the samples was mixed with $9 \mathrm{~mL}$ of inoculated Antibiotic Medium 3 and incubated at $37^{\circ} \mathrm{C}$ for 5 hours in a water bath with circulation. After incubation, the absorbance of the samples, reference substance, and control test tubes was determined at $530 \mathrm{~nm}$. The analyses were accessed in duplicate.

\section{Linearity}

Three doses of reference substance solutions were used $\left(1,2\right.$, and $\left.4 \mu \mathrm{g} \mathrm{mL}^{-1}\right)$ in six independent assays. Results were subjected to regression analysis by the leastsquares method. The graph was obtained using the software Microsoft Excel (2010), by plotting the logarithm of the concentration versus the average of the absorbance values of each solution of DPT reference substance. ANOVA was used to confirm the validity of the assay, and parameters of linearity, parallelism and regression were evaluated.

\section{Precision}

The precision was determined by repeatability and intermediate precision and the results were expressed as relative standard deviation (RSD). Repeatability was evaluated by assaying two independent DPT samples on the same day and under the same experimental conditions (intraday); intermediate precision was evaluated by assaying two independent samples per day, on six different days (inter-day). Sample solutions were prepared according to section "Preparation of reference substance and sample solutions".

\section{Accuracy}

Accuracy was determined by recovering known quantities of the reference substance that was added to the samples. Recovery was determined at three levels named R1, R2 and R3 (70, 100 and $130 \%$ of work concentration). Sample solutions of DPT and reference substance solutions were prepared according to section "Preparation of reference substance and sample solutions". 
Aliquots of $1 \mathrm{~mL}$ of the sample solution $\left(100 \mu \mathrm{g} \mathrm{mL}^{-1}\right)$ and aliquots of $0.4,1.0$ and $1.6 \mathrm{~mL}$ of the reference substance solution $\left(100 \mu \mathrm{g} \mathrm{mL}^{-1)}\right.$ were mixed and diluted with ultrapure water at $100 \mathrm{~mL}$ obtaining a final concentration of $1.4,2.0$ and $2.6 \mu \mathrm{g} \mathrm{mL}^{-1}$ (named R1, R2 and R3 respectively). One milliliter of these final solutions was added to test tubes containing $9 \mathrm{~mL}$ culture medium. The tubes were incubated at $37^{\circ} \mathrm{C}$ for 5 hours in a water bath with circulation. After incubation, the absorbance of samples, reference substance, and control test tubes was determined at $530 \mathrm{~nm}$. The percentage recovery of DPT was calculated.

\section{Robustness}

The robustness was evaluated by analyzing the effect on the assay values promoted by variations in two experimental factors: incubation time and calcium concentration. As incubation time values of 4.5, 5.0 and $5.5 \mathrm{~h}$ were used; the effect of calcium concentration was evaluated at 45, 50 and $55 \mu \mathrm{g} \mathrm{mL}^{-1}$. Both were evaluated in the range of $\pm 10 \%$ around the optimized value. The assays were performed in duplicate.

\section{Degradation kinetics in alkaline medium}

DPT sample solution at $100 \mathrm{ug} \mathrm{mL}^{-1}$ was stored with $0.01 \mathrm{~mol} / \mathrm{L}$ sodium hydroxide during $0,30,60,90$ and 120 minutes. At the end of each exposure time, solutions were neutralized with hydrochloric acid and the concentration was adjusted to $2.5 \mu \mathrm{g} \mathrm{mL}^{-1}$ with water in order to perform a turbidimetric assay and to $25 \mu \mathrm{g} \mathrm{mL}^{-1}$ for an HPLC assay. The assay was performed in duplicate.

The degradation kinetics of solutions was determined by plotting concentration versus time, $1 \mathrm{n}$ of concentration versus time and the reciprocal of concentration versus time (zero-order, first-order and second-order process, respectively). The reaction order was indicated by the best fit to model, indicated by the regression coefficient $(r)$. Parameters such as the degradation rate constant $(k)$, half-life $\left(\mathrm{t}_{1 / 2}\right.$, time to decrease the drug content to $\left.50 \%\right)$ and $t_{90}$ (time for $10 \%$ decomposition) were calculated by equations inherent to the reaction order.

\section{HPLC method}

The chromatographic method, previously reported (Christ et al., 2014), was developed in a Shimadzu ${ }^{\circledR}$ liquid chromatograph with a Waters XBridge C18 column $(250 \mathrm{~mm} \times 4.6 \mathrm{~mm}, 5 \mu \mathrm{m})$. The mobile phase was acetonitrile, methanol and phosphate buffer $\mathrm{pH} 2.2$ $(30: 40: 30 \mathrm{v} / \mathrm{v})$, at a flow rate of $1 \mathrm{~mL} \mathrm{~min}^{-1}$ and isocratic elution. The run time was $10 \mathrm{~min}$ and the injection volume was $20 \mu \mathrm{L}$. DPT was determined by UV detection at $223 \mathrm{~nm}$ using a photodiode-array detector.

\section{Comparison of the methods}

In order to compare the results obtained by the chromatographic method and microbiologic assay, the precision results of both methods were statistically analyzed using two-one-sided-test (TOST) (XLSTAT Version 2015.4.01 for Windows).

\section{RESULTS AND DISCUSSION}

\section{Preliminary studies}

The potency of antibiotics in pharmaceuticals can be assessed by a cylinder-plate assay (also known as agar diffusion assay) and the turbidimetric assay. Agar diffusion is usually the method of choice when the characteristics of an antibiotic allow for using it (particularly water-soluble compounds). Turbidimetric assay is used less widely than the diffusion assay, although it might be considered to resemble the clinical situation more closely. It is more commonly used to assay antibiotics that are poorly soluble in water (Baird, Hodges, Denyer, 2000).

Our first attempts were aimed at developing an agar diffusion method, considering its widespread usage and the aqueous solubility of DPT. We used the $3 \times 3$ design, in a bilayer system with six plates for each assay. Staphylococcus aureus ATCC $6538 \mathrm{p}$ was selected and the culture media were the most used for this microorganism (USP, 2007; ANVISA, 2010) (Antibiotic Medium 1 and Antibiotic Medium 2). DPT solutions in a wide range were tested ( 1.5 to $\left.80 \mu \mathrm{g} \mathrm{mL}^{-1}\right)$ and, according to the results, DPT concentrations of 8,16 , and $32 \mu \mathrm{g} \mathrm{mL}^{-1}$ were chosen. The plates were prepared and, after incubation $\left(37^{\circ} \mathrm{C} / 18\right.$ hours), the inhibition zones formed by the reference substance and sample solutions were compared (ANVISA, 2010).

The mean inhibition zones obtained for the DPT reference substance were $12.11 \mathrm{~mm} \pm 3.23,14.44 \mathrm{~mm}$ \pm 1.79 , and $16.26 \mathrm{~mm} \pm 2.12$, for 8,16 and $32 \mu \mathrm{gLL}^{-1}$, respectively. These results show the method's inability to detect differences in drug content, since only small changes were observed in the inhibition zones, in spite of the wide concentration range used. Similar responses are reported for other drugs with a high molecular weight, such as vancomycin, teicoplanin, and polymyxins and are attributed to their difficulty in diffusing in solid media (Koeth, Thorne, 2010). Considering these results, we gave 
up on the agar diffusion assay and started to develop the turbidimetric assay.

\section{Calcium concentration}

The effect of calcium on the action mechanism of DPT was initially reported in 1986 (Eliopoulos et al., 1986). A subsequent study demonstrated that DPT MICs are generally twofold to fourfold lower when tested in broth containing $50 \mu \mathrm{g} \mathrm{mL}^{-1}$ of calcium (Fuchs, Barry, Brown, 2000). Another more recent study also confirms the results obtained in previous studies, suggesting the important presence of calcium in susceptible assays using culture medium containing or supplemented with $50 \mu \mathrm{g} \mathrm{mL}^{-1}$ of calcium (Koeth, Thorne, 2010).

Tests with and without calcium were performed by the two methods studied in order to verify the need for calcium in the microbiological assay. In both methods, calcium was added to the culture media after sterilization. The means of the diameter zones without calcium were $8.37,9.36$, and $10.23 \mathrm{~mm}$, respectively and $13.05,14.99$, and 16.33 with calcium (agar diffusion assay). The absorbances that were found in the assay with calcium were $0.275,0.167$, and 0.067 , and without calcium they were $0.271,0.287$, and 0.289 . These results demonstrated that in the absence of calcium there was visibly less antimicrobial activity than when calcium was used at $50 \mu \mathrm{g} \mathrm{mL} L^{-1}$.

\section{Turbidimetric assay}

Several assays under different conditions were conducted to establish the optimal conditions to develop the turbidimetric method (Table I). The best results were found under the following conditions: Antibiotic Medium 3 (fluid), supplemented with calcium; inoculum concentration at $1.0 \%$ (Staphylococcus aureus ATCC $6538 \mathrm{p}) ; 5$ hours of incubation $\left(37^{\circ} \mathrm{C}\right)$ and reference substance and sample solutions at 1.0, 2.0, and $4.0 \mu \mathrm{g}$ $\mathrm{mL}^{-1}$, diluted in water. Staphylococcus aureus was used considering the microbial activity of DPT. Time and temperature of incubation are in agreement with the recommended values for this microorganism. Absorbance values in the range of 0.1 to 0.5 are considered indicative of the suitability of the conditions employed (Baird, Hodges, Denyer, 2000); thus, they were used to define the inoculum concentration. Water was used to dilute the sample considering the high DPT aqueous solubility.

\section{Specificity}

According to the literature (Alsante et al., 2007), degradation in the range of $5-20 \%$ is sufficient to show that there is no interference of degradation products in the tests performed under acidic or basic conditions. Preliminary tests indicated a high degradation rate in the alkaline medium. Thus, we employed $0.01 \mathrm{~mol} / \mathrm{L}$ $\mathrm{NaOH}$, at room temperature. Samples were assayed by the bioassay and HPLC methods, respectively, and similar results were found, $86.9 \%(\mathrm{n}=2$, RSD $3.16 \%)$ and $82.4 \%(n=3$, RSD $1.78 \%)$. These results confirmed the stability characteristic of the assay, since it showed the sample potency against a microorganism, in the presence of degradation products.

\section{Linearity}

The calculation procedure usually assumes a direct relationship between the absorbance and logarithm of the respective dose. The corresponding mean absorbances for the reference substance solutions were: 0.3035 for the lower dose $\left(1 \mu \mathrm{g} \mathrm{mL}^{-1}\right), 0.1995$ for the intermediate dose $\left(2 \mu \mathrm{g} \mathrm{mL}^{-1}\right)$, and 0.1058 for the higher dose $\left(4 \mu \mathrm{g} \mathrm{mL}^{-1}\right)$. The dose-response lines for DPT solutions (sample and reference substance) were constructed by plotting log concentrations $\left(\mu \mathrm{g} \mathrm{mL}^{-1}\right)$ versus absorbance and showed good linearity between the range of 1 and $4 \mu \mathrm{g} \mathrm{mL} \mathrm{m}^{-1}$. The representative linear equation for DPT reference substance was $\mathrm{y}=-0.3284 \log (\mathrm{x})+0.3018, \mathrm{r}=0.9995$ for DPT sample. According to ANOVA, the assay showed significant regression $(\mathrm{p}<0.05)$ and no deviation from linearity and from parallelism $(\mathrm{p}>0.05)$, meeting the requirements of $3 \times 3$ design (FB 5, 2010).

TABLE I - Conditions tested to establish the turbidimetric assay conditions

\begin{tabular}{ll}
\hline Parameters & Conditions \\
\hline Standard curve points $(\mu \mathrm{g} / \mathrm{mL})$ & $0.1,0.25$ and $0.5 ; 0.5,1.0$ and $2.0 ; 1.0,2.0$ and 4.0 \\
Culture medium & Casoy Broth; Antibiotic Medium 3 \\
Inoculum concentration $(\%)$ & $0.2 ; 0.4 ; 0.5 ; 0.8$ and 1.0 \\
Incubation time (hours) & $3.0 ; 4.0$ and 5.0 \\
\hline
\end{tabular}




\section{Precision}

The precision of the assay was evaluated at two levels: repeatability (intra-day, $n=2 /$ day) and intermediate precision (inter-day, 6 days) and the results are expressed as the RSD of the measurement series (Table II). The potency of the sample was calculated by the Hewitt equation, which compares the dose-response lines from the sample and reference substance. Low RSD values were obtained, confirming the precision of this method.

\section{Accuracy}

The accuracy of the bioassay proposed was accessed by the standard addition method. The results obtained showed good recovery of the drug added to the sample solutions (Table III). The mean recovery value was $100.48 \%$ and RSD $2.11 \%$, which confirms the suitability of the analytical conditions employed and ensures the ability of the method to quantify DPT concentrations within the range of 70 to $130 \%$ of the target value.

\section{Robustness}

The results of the robustness evaluation are shown in Table IV. The results obtained indicate that the modifications in the method parameters did not cause significant differences in the DPT assay ( $\mathrm{p}>0.05)$.

\section{Kinetic degradation}

A linear relationship between the $\ln$ of the remaining concentrations versus time was observed. This indicated that the reaction of DPT degradation under the condition evaluated followed first-order kinetics and that the degradation rate depends on the reagent concentration (Lachman, Lieberman, Kanig, 2001). The rate constant order (k) was determined by the graphic equation

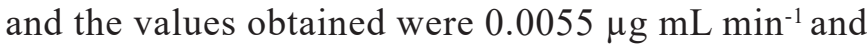

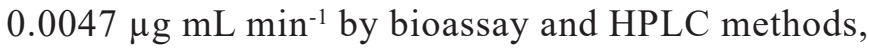
respectively.

Through the data obtained it was also possible to determine the half-life and $t_{90}$ of daptomycin under the

TABLE II - Values obtained in the determination of daptomycin (DPT) injection by turbidimetric assay

\begin{tabular}{lcccccc}
\hline \multirow{2}{*}{ Sample } & \multicolumn{7}{c}{ Potency (\% of label claim) } \\
\cline { 2 - 6 } & Day 1 & Day 2 & Day 3 & Day 4 & Day 5 & Day 6 \\
\hline 1 & 100.88 & 98.15 & 97.22 & 102.64 & 104.31 & 102.02 \\
2 & 100.22 & 99.18 & 97.72 & 104.38 & 104.11 & 100.65 \\
Mean intra-day & 100.55 & 98.67 & 97.47 & 103.51 & 104.21 & 101.34 \\
RSD Intra-day & 0.46 & 0.74 & 0.36 & 1.19 & 0.14 & 0.96 \\
Mean inter-day & 100.96 & & & & \\
RSD inter-day & 2.58 & & & & & \\
\hline
\end{tabular}

TABLE III - Accuracy of the turbidimetric assay

\begin{tabular}{|c|c|c|c|c|c|}
\hline Sample & $\begin{array}{l}\text { Reference substance } \\
\text { added }(\mu \mathrm{g} / \mathrm{mL})\end{array}$ & $\begin{array}{c}\text { Concentration } \\
\text { recovered }(\mu \mathrm{g} / \mathrm{mL})\end{array}$ & Recovery (\%) & Mean (\%) & RSD (\%) \\
\hline \multirow[t]{3}{*}{$\overline{\mathrm{R} 1}$} & 0.4 & 0.3849 & 96.23 & & \\
\hline & & 0.3942 & 100.75 & 98.51 & 2.29 \\
\hline & & 0.4025 & 98.55 & & \\
\hline \multirow[t]{3}{*}{$\mathrm{R} 2$} & 1.0 & 1.0085 & 100.85 & & \\
\hline & & 1.0152 & 101.84 & 101.40 & 0.50 \\
\hline & & 1.0184 & 101.52 & & \\
\hline \multirow[t]{5}{*}{ R3 } & 1.6 & 1.5927 & 99.54 & & \\
\hline & & 1.6517 & 101.82 & 102.29 & 0.80 \\
\hline & & 1.6294 & 103.23 & & \\
\hline & & Mean recovery $(\%)$ & & 100.48 & \\
\hline & & RSD & & 2.09 & \\
\hline
\end{tabular}


TABLE IV - Robustness determination of the DPT turbidimetric assay

\begin{tabular}{|c|c|c|c|c|c|}
\hline & \multicolumn{5}{|c|}{ Daptomycin assay (\% of theoretical value) } \\
\hline & \multirow{2}{*}{$\begin{array}{l}\text { Optimized } \\
\text { condition* }\end{array}$} & \multicolumn{2}{|c|}{ Calcium concentration $\left(\mu \mathrm{g} \mathrm{mL}^{-1}\right)$} & \multicolumn{2}{|c|}{ Incubation time (h) } \\
\hline & & 55 & 45 & 4.5 & 5.5 \\
\hline Assay 2 & 100.44 & 99.89 & 101.13 & 100.40 & 99.19 \\
\hline
\end{tabular}

* calcium concentration at $50 \mu \mathrm{g} \cdot \mathrm{mL}^{-1}$, incubation time 5 hours.

degradation condition employed. The obtained values were 128.37 and 19.36 minutes $\left(\mathrm{t}_{1 / 2}\right.$ and $\mathrm{t}_{90}$, turbidimetric bioassay) and 130.81 and 22.55 minutes ( $\mathrm{t}_{1 / 2}$ and $\mathrm{t}_{90}$, HPLC assay). These data are in agreement with the experimental values (degradation of $43.5 \%$ in 120 minutes, turbidimetric bioassay). The results of the two methods indicated that both produce a similar percentage remaining of DPT (Figure 2).

Furthermore, the analyses of degraded solutions confirmed the sensitivity of the biological assay to quantify DPT in degraded samples and showed that DPT degradation products do not present bactericidal activity. This is important information for the health-system pharmacists, in the sense of avoiding dilution with alkaline diluents, such as sodium bicarbonate.

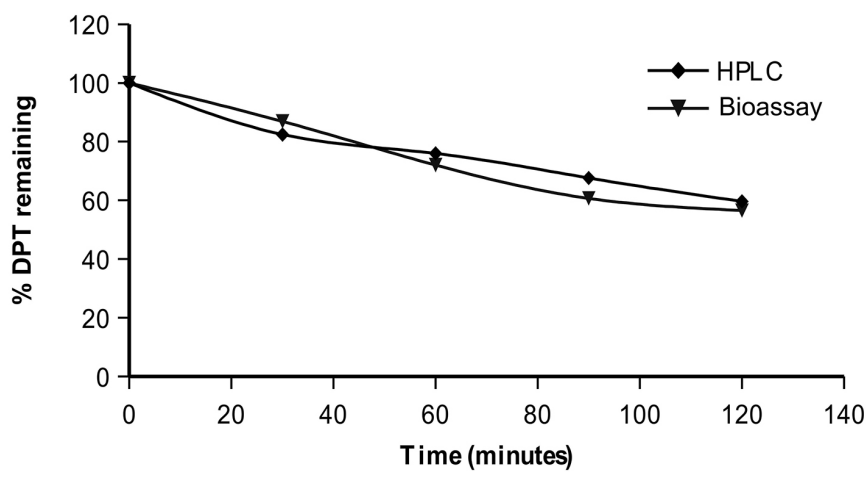

FIGURE 2 - DPT assay after alkaline degradation at 0, 30, 60, 90 and 120 minutes of exposure, by the turbidimetric bioassay and HPLC methods.

Conversely, residual samples of DPT must be discarded $24 \mathrm{~h}$ after reconstitution, according to the manufacturer's recommendation. Thus, the obtained results suggest that DPT solutions can be treated with alkaline solutions before being discarded, contributing to the reduction of environmental damage.

\section{Comparison of methods}

The results obtained in the turbidimetric bioassay were compared to those obtained by the HPLC method, previously validated by our group (Christ et al., 2014). By microbiological assay, the mean potency (potency $\pm \mathrm{RSD} \%, \mathrm{n}=12)$ was $100.96 \pm 2.58$ and by the HPLC method it was $100.23 \pm 0.59$ (assay $\pm \mathrm{RSD} \%, \mathrm{n}=12$ ). These results were statistically evaluated by the two-onesided-test (TOST), considering a significance level of 5\% and confidence interval of $90 \%$. The null hypothesis can be accepted and consequently, the analytical methods considered equivalent when the confidence interval for the difference is completely contained within the defined range considered to be scientifically trivial $( \pm \Delta)$. We defined $\Delta=5$ as an appropriate range for the equivalence testing, based on the specifications of the precision test (RSD $=5 \%$, ANVISA, 2003), and on the inherent variation of biological assays. TOST was applied and indicated equivalence between the two methods, as shown in Table V.

TABLE V - TOST results for the comparison of the microbiological and HPLC methods

\begin{tabular}{lc}
\hline Test & Value \\
\hline Lower bound (TOST) & $-5,000$ \\
Lower bound (90\%) & $-0,582$ \\
Upper bound (90\%) & 2,038 \\
Upper bound (TOST) & 5,000 \\
Test interpretation & Equivalent \\
\hline
\end{tabular}

$\alpha=0.05$

The quantification of antibiotics by chemical methods, such as HPLC, presents some advantages such as shorter analysis time, possibility of automation, lower RSD values, and shorter time to review the robustness. Disadvantages can be the high cost of equipment and the large amounts of organic solvents used. Besides, the method cannot truly show biologic activity.

Biological methods have some advantages in comparison to methods like HPLC and UV spectrophotometry, such as the low cost of the equipment 
(Manfio et al., 2013), the good relationship with clinical use, and they can determine the content and the biological activity. In spite of the high variability expected from the bioassays, in our study the RSD values obtained in precision evaluation are within the recommended limits. Therefore, this assay could be very useful to determine DPT in pharmaceutical dosage forms.

\section{CONCLUSION}

The proposed turbidimetric bioassay proved to be able to quantify the DPT injection. Although an agar diffusion assay is more used to quantify antimicrobials, the turbidimetric assay is faster and the measure of the response is automated. The method was validated according to $\mathrm{ICH}$ guidelines and demonstrated good linearity, precision, accuracy, robustness, specificity, and stability-indication. Therefore, it is an acceptable method for the routine quality control of daptomycin and useful in stability studies.

\section{ACKNOWLEDGEMENTS}

The authors wish to thank CAPES (Brazil) for their financial support, Hospital Universitário de Santa Maria (HUSM) for providing the samples, Cristalia (Brazil) for providing the reference substance, Laboratório de Farmacotécnica (UFSM) for lending the equipment.

\section{REFERENCES}

AGÊNCIA BRASILEIRA DE VIGILÂNCIA SANITÁRIA. ANVISA. Farmacopeia brasileira. 5. ed. Brasília: Anvisa 2010. p. 261-272.

ALSANTE, K.M.; ANDO, A.; BROWN, R.; ENSING, J.; HATAJIK, T.D.; KONG, W.; TSUDA, Y. The role of degradant profiling in pharmaceutical ingredients and drug products. Adv. Drug Deliv. Rev., v.59, n.1, p.29-37, 2007.

AGÊNCIA NACIONAL DE VIGILÂNCIA SANITÁRIA. ANVISA. Resolução-RE n 899 , de 29 de maio de 2003. Determina a publicação do "Guia para validação de métodos analíticos e bioanalíticos"; fica revogada a Resolução RE n475 de 19 de março de 2002. Brasília: Visalegis, 2003. Available at: <http://portal.anvisa.gov.br/ wps/wcm/connect/4983b0004745975da005f43fbc4c6735/ RE 8992003 Determina $+a+$ publica $\%$ C3\%A7\%C3\%A3 $\mathrm{o}+$ do + Guia + para + valida $\% \mathrm{C} 3 \% \mathrm{~A} 7 \% \mathrm{C} 3 \% \mathrm{~A} 3 \mathrm{o}+\mathrm{de}+\mathrm{m} \% \mathrm{C} 3$ $\%$ A9todos+anal\%C3\%ADticos+e+bioanal\%C3\%ADticos. pdf?MOD=AJPERES $>$. Accessed on: Aug. 2015.
BAIETTO, L.; D'AVOLIO, A.; ROSA, F.G.; GARAZZINO, S.; MICHELAZZO, M.; VENTIMIGLIA, G.; SICCARDI, M.; SIMIELE, M.; SCIANDRA, M.; DI PERRI, G. Development and validation of a simultaneous extraction procedure for HPLC-MS quantification of daptomycin, amikacin, gentamicin, and rifampicin in human plasma. Anal. Bioanal. Chem., v.396, n.2, p.791-798, 2010.

BAIRD, R.M.; HODGES, N.A.; DENYER, S.P. Handbook of microbiological quality control: pharmaceuticals and medical devices. Boca Raton, FL: CRC Press, 2000. 251 p.

BOUCHER, H.W.; TALBOT, G.H.; BENJAMIN JR.; D.K.; BRADLEY, J.; GUIDOS, R.J.; JONES, R.N.; MURRAY, B. E.; BONOMO, R.A.; GILBERT, D. 10 X '20 Progress - Development of new drugs active against gram-negative bacilli: An update from the infectious diseases society of America. Clin. Infect. Dis., v. 56, n.12, p.1685-1694, 2013.

CHRIST, A.P.; MACHADO, M.S.; ROSA, P.; CODEVILLA, C.F.; ROLIM, C.M.B.; ADAMS, A.I.H. Development and validation of a stability-indication LC-UV method for determination of daptomycin injectable form and kinetic study in alkaline medium. Anal. Methods, v. 6, n.4, p.12421247,2014

DEBONO, M.; BARNHART, M.; CARRELL, C.B.; HOFFMANN, J.A.; OCCOLOWITZ, J.L.; ABBOTT, B.J.; FUKUDA, D.S.; HAMILL. R.L. A21978C, a complex of new acidic peptide antibiotics: Isolation, chemistry, and mass spectral structure elucidation. J. Antibiot., v.40, n.6, p.761-777, 1987.

DERYKE, C.A.; SUTHERLAND, C.; ZHANG, B.; NICOLAU, D.P.; KUTI, J.L. Serum bactericidal activities of highdose daptomycin with and without co administration of gentamycin against isolates of Staphylococcus aureus and Enterococcus species. Antimicrob. Agents Chemother., v.50, n.11, p.3529-3534, 2006

DVORCHIK, B.H.; BRAZIER, D.; DEBRUIN, M.F.; ARBEIT, R.D. Population pharmacokinetics of daptomycin. Antimicrob. Agents Chemother., v.47, p.13-18, 2003.

ELIOPOULOS, G.M.; WILLEY, S.; REISZNER, E.; SPITZER, P.G.; CAPUTO, G.; MOELLERING JR, R.C. In vitro and in vivo activity of LY146032, a new cyclic lipopeptide antibiotic. Antimicrob. Agents Chemother., v.30, n.4, p.532$535,1986$. 
EOM, S.H.; KIM, Y.M.; KIM, S.K. Marine bacteria: potential sources for compounds to overcome antibiotic resistance. Appl. Microbiol. Biotechnol., v.97, n.11, p.4763-4773, 2013.

FERNANDES, P. Antibacterial discovery and development - the failure of success? Nat. Biotechnol., v.24, n.12, p.1497$1503,2006$.

FUCHS, P.C.; BARRY, A.L.; BROWN, S.D. Daptomycin susceptibility tests: interpretative criteria, quality control, and effect of calcium in vitro tests. Diagn. Microbiol. Infect. Dis., v.38, n.1, p.51-58, 2000.

GIKAS, E.;BAZOTI,F.N.;FANOURGIAKIS, P.; PERIVOLIOTI, E.; ROUSSIDIS, A.; SKOUTELIS, A.; TSARBOPOULOS, A. Development and validation of a UPLC-UV method for the determination of daptomycin in rabbit plasma. Biomed. Chromatogr., v.24, n.5, p.522-527, 2009.

HEWITT, W. Microbiological assay for pharmaceutical analysis: a rational approach. Boca Raton, FL, USA: Interpharm/CRC Press, 2003.

INTERNATIONAL CONFERENCE ON HARMONIZATION. ICH. Validation of analytical procedures: text and methodology Q2(R1). Geneva: IFPMA, 2005. Available at: <http://www.ich.org/fileadmin/Public_Web_Site/ ICH_Products/Guidelines/Quality/Q2_R1/Step4/Q2_R1 Guideline.pdf $>$. Accessed on: Aug. 2015.

KOETH, L.M.; THORNE, G.M. Daptomycin in vitro susceptibility methodology: a review of methods, including determination of calcium in testing media. Clin. Microbiol. Newsl., v.32, n.21, p.161-169, 2010.

LACHMAN, L.; LIEBERMAN, H.A.; KANIG, J.L. Teoria e prática na indústria farmacêutica. Lisboa: Fundação Calouste Gulbenkian, 2001.

LU, W.; FAN, J.; WEN, J.; XIA, Z.; CAIYIN, Q. Kinetic analysis and modeling of daptomycin batch fermentation by Streptomyces roseosporus. Appl. Biochem. Biotechnol., v.163, n.4, p.453-462, 2011.

MANFIO, M.L.; AGARRAYUA, D.A.; MACHADO, J.C.; SCHMIDT, C.A. A fully validated microbiological assay to evaluate the potency of ceftriaxone sodium. Braz. J. Pharm. Sci., v.49, n.4, p.753-762, 2013.
MARTENS-LOBENHOFER, J.; KIELSTEIN, J. T.; OYE, C.; BODE-BOGER, S.M. Validated high performance liquid chromatography-UV detection method for the determination of daptomycin in human plasma. J. Chromatogr. B., v.875, n.2, p.546-550, 2008.

OLSZOWY, P.; SZULTKA, M.; FUCHS, P.; KEGLER, R.; MUNDKOWSKI, R.; MIEKISCH, W.; SCHUBERT, J.; BUSZEWSKI, B. New coated SPME fibers for extraction and fast HPLC determination of selected drugs in human blood. Pharm. Biomed. Anal., v.53, n.4, p.1022-1027, 2010.

RYBAK, M.J.; BAILEY, E.M.; LAMP, K.C.; KAATZ, G.W. Pharmacokinetics and bactericidal rates of daptomycin and vancomycin in intravenous drug abusers being treated for Gram-positive endocarditis and bacteremia. Antimicrob. Agents Chemother., v.36, n.5, p.1109-1114, 1992.

SAKOULAS, G. Clinical outcomes with daptomycin: a postmarketing, real-world evaluation. Clin. Microbiol. Infect., v.15, n.6, p.11-16, 2009.

SPELLBERG, B.; GUIDOS, R.; GILBERT, D.; BRADLEY, J.; BOUCHER, H.W.; SCHELD, W.M.; BARLETT, J.G.; EDWARDS JR. J. The epidemic of antibiotic-resistant infections: A call to action for the medical community from the Infectious Diseases Society of America. Clin. Infect. Dis., v.46, n.2, p.155-164, 2008.

STEENBERGEN, J.N.; ALDER, J.; THORNE, G.M.; TALLY, F.P. Daptomycin: a lipopeptide antibiotic for the treatment of serious Gram-positive infections. J. Antimicrob. Chemoter., v.55, n.3, p.283-288, 2005.

TOBIN, C.M.; DARVILLE, J.M.; LOVERING, A.M.; MACGOWAN,A.P.An HPLC assay for daptomycin in serum. J. Antimicrob. Chemother., v.62, n.6, p.1462-1476, 2008.

UNITED STATES PHARMACOPOEIA USP. USP $30 \mathrm{ed}$. Rockville: The United States Pharmacopeial Convention, 2007. 1248 p.

VERDIER, M.C.; BENTUÉ-FERRER, D.; TRIBUT, O.; COLlET, N.; REVEST, M.; BELlisAnt, E. Determination of daptomycin in human plasma by liquid chromatography-tandem mass spectrometry. Clin. Chem. Lab. Med., v.49, n.1, p.69-75, 2011.

Received for publication on $15^{\text {th }}$ January 2015 Accepted for publication on $24^{\text {th }}$ August 2015 
